\title{
ANTIPROLIFERATIVE ACTIVITY OF BERBERINE IN VITRO AND IN VIVO
}

\author{
Silvia Letašiováa, Soňa Jantováa, Marta Múčkováb, Marica Theiszováa \\ a Department of Biochemistry and Microbiology, Faculty of Chemical and Food Technology, Slovak University of Technology, \\ Radlinského 9, SK-81237 Bratislava, Slovak Republic \\ b Drug Research Institute, Horná 36, SK-90001 Modra, Slovak Republic \\ e-mail: silvia.letasiova@stuba.sk
}

Received: June 10, 2005; Accepted: September 25, 2005

Key words: Berberine/B16 cells/C57BL/6 mice/Antiproliferative activity

Berberine, an isoquinoline plant alkaloid acted cytotoxically in vitro on tumour cell lines B16. Its anticancer activity in vivo was studied with the transplanted B16 line in the range of doses from $1 \mathrm{mg} / \mathrm{kg}$ to $10 \mathrm{mg} / \mathrm{kg}$. The significant reduction of tumor volume was observed on day 16 at doses of 5 and $10 \mathrm{mg} / \mathrm{kg}$. The dose of $1 \mathrm{mg} / \mathrm{kg}$ stimulated the tumor mass, but other tested concentration, 5 and $10 \mathrm{mg} / \mathrm{kg}$, reduced the tumor weight.

\section{INTRODUCTION}

Berberine (2,3-methylenedioxy-9,10-dimethoxyprotoberberine chloride) is an isoquinoline alkaloid, which has a wide range of pharmacological and biochemical effects. It has demonstrated significant antimicrobial activity against a variety of organisms including bacteria, fungi, protozoans, viruses, chlamydia, and helminths. It can also be used as an antidiarrhea, antihypertension, antiarrhythmias and antiiflamantory agent. Berberine is demonstrated to possess antitumor activity ${ }^{1}$. The cell cycle analysis showed the accumulation of cells in the $\mathrm{G}_{0} / \mathrm{G}_{1}$ phase and relative decrease of the $\mathrm{S}$ phase. Chung et al. ${ }^{2}$ reported that berberine induces inhibition of the N-acetyltransferase activity and 2-aminofluorene-DNA adduct formation in human leukemia cell in a dose-dependent manner. It has been shown that berberine induces apoptosis in the murine thymocytes and in the promyelocytic leukemic HL-60 cells. Dose-dependent effects of berberine on the cell cycle and apoptosis in the Balb/c 3T3 cells were also reported. The effect of berberine was demonstrated by flow cytometric analysis in the human hepatoma HepG 2 cells. It has been shown that the $\mathrm{S}$ phase fraction is significantly reduced.

In the previous experiments the effect of berberine on the proliferation, cell cycle profile and apoptosis in the human tumor HeLa and murine leukemia L1210 cell lines was investigated. It has been shown that berberine induces apoptosis in L1210 cells ${ }^{3}$. In this study, the antiproliferative activity in vitro on murine melanoma B16 cells and in vivo on male C57BL/6 mice was studied.

\section{MATERIAL AND METHODS}

Murine melanoma cell line B16 (obtained from American Type Culture Collection, Rockville, MD, USA) grown in supplemented RPMI 1640 medium (Biocom
Bratislava) at $37^{\circ} \mathrm{C}$ in a humidified atmosphere containing $5 \% \mathrm{CO}_{2}$ was used. Cell viability was assessed by $0.4 \%$ trypan blue staining. To study the antiproliferative activity in vivo, 5-6-week-old male C57BL/6 mice obtained from Velaz (Czech Republic) were used. Berberine obtained from Sigma Chemicals (St Louis, MD) was dissolved in dimethyl sulfoxide (DMSO). All other chemicals were obtained from Sigma Chemicals (St Louis, MD).

Antiproliferative activity in vitro was measured by the cell growth inhibition assay. The starting inoculum of 1.34 $\times 10^{5} \mathrm{~B} 16$ cells $/ \mathrm{ml}$ was used. After $24 \mathrm{~h}$ of incubation, berberine (concentrations of $0.001,0.01,0.1,1,5,10,25,50$, 75 and $100 \mu \mathrm{g} / \mathrm{ml}$ ) was added to the cells. Control cells were treated with DMSO, its final concentration never exceeded $1 \%$. After 24, 48 and $72 \mathrm{~h}$ of berberine treatment, B16 cells were harvested in triplicate, first washed with PBS, then harvested by $0.25 \%$ trypsin, and latter resuspended. Cell growth and viability were assessed by direct counting of $0.4 \%$ trypan blue dye-excluding cells.

When studying the antiproliferative activity in vivo, cell suspensions of B16 cells $\left(5 \times 10^{4} / 0.1 \mathrm{ml}\right.$ PBS / mouse $)$ were injected into gastrocnemius muscle of mice. The day of cell implantation was designed as day 0 . Tested compound, berberine, and vehicle, respectively were administered intraperitoneally every day within 15 days from the day of cancer cell injection. As a vehicle carboxymethylcellulose was used. The group treated with carboxymethylcellulose was designed as the control. Berberine was used at concentrations of 1,5 and $10 \mathrm{mg} / \mathrm{kg}$. Doses were selected on the basis of the toxicity test. The weight of the animals was monitored twice per week. The physical activity of the mice was observed daily. Tumor growth was measured twice per week and tumor volume was estimated by the formula length $\times$ width $^{2} / 2$. At the end of the experiment, on day 16 , the animals were sacrificed with cervical dislocation. The tumors were separated from the surrounding muscles and dermis, excised and weighed. 


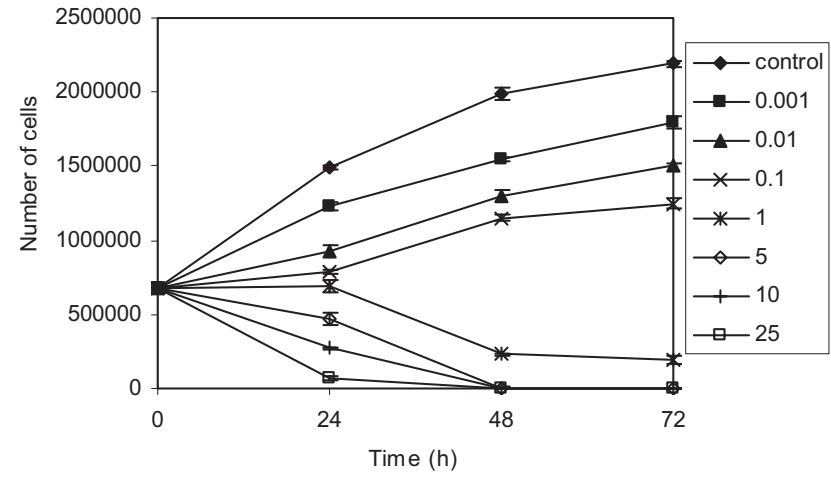

Fig. 1. Growth curve of the berberine treated B16 cells in the course of $72 \mathrm{~h}$. Concentrations of berberine $(\mu \mathrm{g} / \mathrm{ml})$ : control $(\diamond), 0.001(\square), 0.01(\Delta), 0.1(\times)$, $1($ ж), $5(\diamond), 10(+), 25(\square)$. Each point represents the mean \pm SD of three experiments.

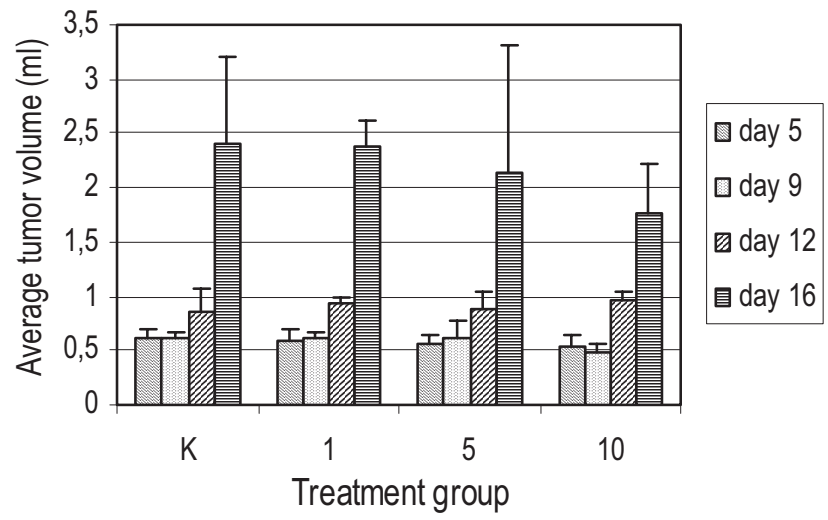

Fig. 3. Growth of tumors after intramuscular injection of B16 cells. Mice were intraperitoneally treated with carboxymethylcellulose as control (C) and berberine at concentrations of $1(1), 5$ (5) and $10(10) \mathrm{mg} /$ $\mathrm{kg}$. The animals were measured on day $0,5,9,12$ and 16 . Data represent the arithmetic means \pm SE. Statistically significant differences with $\mathrm{P}<0.05$ are indicated with *.

The data from in vitro and in vivo study were presented as means \pm s.e. (standard errors). The statistical significance of the results was evaluated by Student's t-test, with probability values of 0.05 being considered as significant.

\section{RESULTS AND DISCISSION}

The growth of B16 cells exposed to berberine at concentrations ranging from 0.001 to $25 \mu \mathrm{g} / \mathrm{ml}$ was monitored within $72 \mathrm{~h}$ of culturing (Fig. 1). As shown in Fig. 1, the addition of berberine to the medium reduced the $\mathrm{B} 16$ viable cell number. After $24 \mathrm{~h}$, the highest tested concentrations $(25,10$ and $5 \mu \mathrm{g} / \mathrm{ml})$ had an acute cytotoxic effect

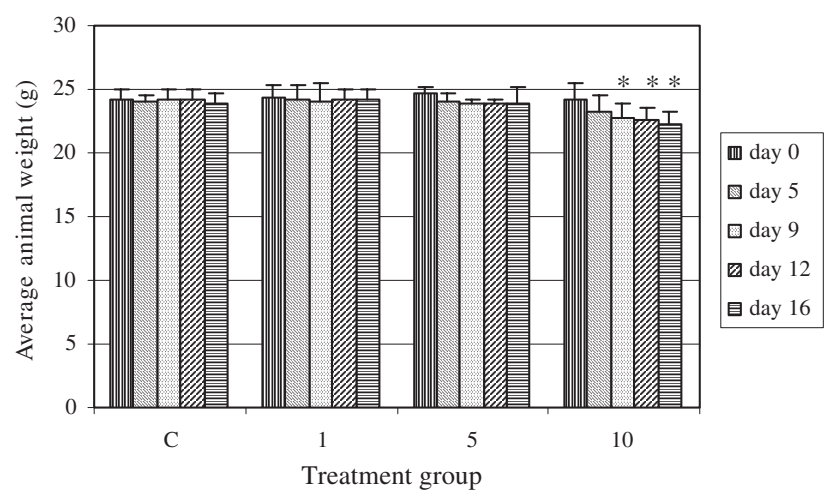

Fig. 2. Weight of animals after intramuscular implatation of B16 cells. Mice were intraperitoneally treated with carboxymethylcellulose as control (C) and tested compound, berberine, at concentrations of $1(1), 5(5)$ and $10(10) \mathrm{mg} / \mathrm{kg}$. The animals were weighed on day $0,5,9,12$ and 16. Data represent the arithmetic means \pm SE. Statistically significant differences with $\mathrm{P}<0.05$ are indicated with *.

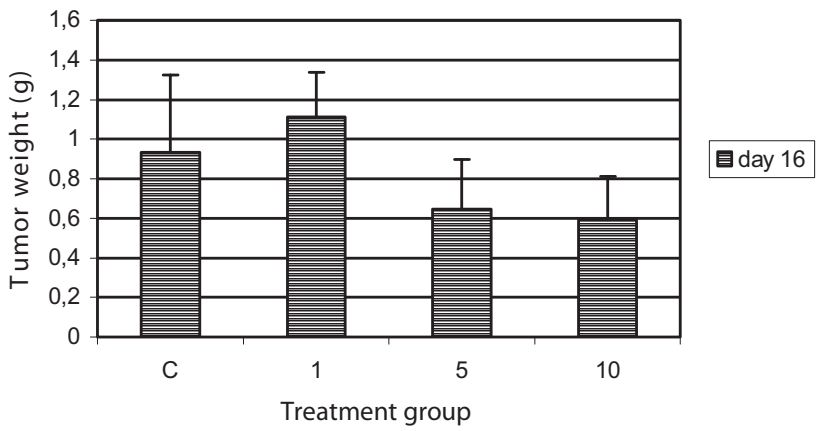

Fig. 4. Weight of tumors formed in mice 16 days after intramuscular injection of B 16 cells. C57BL/6 mice were intraperitoneally treated with carboxymethylcellulose as control (C) and berberine at concentrations of 1,5 and $10 \mathrm{mg} / \mathrm{kg}$. Data represent the means $\pm \mathrm{SE}$.

manifested by partial degeneration of the $\mathrm{B} 16$ cell populations. Berberine at concentrations of $1 \mu \mathrm{g} / \mathrm{ml}$ for the B 16 cells induced a delayed cytotoxic effect. After $24 \mathrm{~h}$, part of the cell population proliferated, but after 48 h, $64.9 \%$ of the cell degeneration was observed. The cytotoxic effect of berberine at the next tested concentrations $(0.1$, 0.01 and $0.001 \mu \mathrm{g} / \mathrm{ml}$ ) was directly proportional to the concentration and the time of influence. The inhibition of cell proliferation was 32.7-86.1\%. These changes in viable cell number were also observed when aliquots of the cultures were examined by light microscopy.

The weight of the animals treated with 1, 5 and $10 \mathrm{mg} / \mathrm{kg}$ in comparison with control is shown in Fig. 2. The injected animals were weighed twice per week, on 
day $0,5,9,12$ and 16 . The weight of carboxymethylcellulose-injected animals did not changed remarkably during the experiment. The weights of the animals treated with berberine at concentrations of 1 and $5 \mathrm{mg} / \mathrm{kg}$ did not differ from the weight of the control group. On the other hand, the weight of the animals treated with berberine at concentration of $10 \mathrm{mg} / \mathrm{kg}$ was slightly decreased by $3.3 \%$ on day 5 compared to the control, but in the next time interval, on day 9 , the decrease was $5.8 \%$ in comparison with the control on day 9 . On day 12 , the weight decrease between animals treated with $10 \mathrm{mg} / \mathrm{kg}$ and control was $6.6 \%$. In the next time interval, on day 16 , the weight was inhibited by $6.7 \%$. The statistically significant differences were observed when comparing the highest tested concentration, $10 \mathrm{mg} / \mathrm{kg}$, with the control on day 9,12 and 16 .

The injected animals were also examined twice per week for tumor growth. Five days following cell inoculation, the appearance of small solid tumors was observed. Concentrations 1,5 and $10 \mathrm{mg} / \mathrm{kg}$ injection did not reduce tumor volume on day 5, 9 and 12 in comparison with the control (Fig. 3). On day 16, the dose of $1 \mathrm{mg} / \mathrm{kg}$ reduced tumor volume by $1.1 \%, 5 \mathrm{mg} / \mathrm{kg}$ by $11.3 \%$ and $10 \mathrm{mg} / \mathrm{kg}$ by $26.2 \%$ compared to carboxymethylcelluloseinjected animals. The statistically significant difference was observed when comparing the highest tested dose, $10 \mathrm{mg} / \mathrm{kg}$, with the control on day $9(\mathrm{P}=0.046)$.

By day 16, the group treated with berberine at dose of $1 \mathrm{mg} / \mathrm{kg}$ grew slightly bigger tumors than carboxymethylcellulose-treated animals (Fig. 4). However, there was no statistically significant difference between the two groups $(P=0.14)$. Tumor mass in animals treated with $5 \mathrm{mg} / \mathrm{kg}$ was reduced by $30.8 \%$ compared to the control group with statistically significant difference $(\mathrm{P}=0.014)$. Injection of berberine at concentration of $10 \mathrm{mg} / \mathrm{kg}$ resulted in similar tumor mass reduction as that induced by $5 \mathrm{mg} / \mathrm{kg}$ compared to the control group, reduction was $36.6 \%$. However, there was no statistically significant difference between the two groups $(\mathrm{P}=0.08)$.

As it follows from the growth curves of the B16 cells (Fig. 1), berberine caused different cytotoxic effects depending on concentration and time of influence. The highest tested concentrations of berberine induced an acute cytotoxic effect which was manifested by the decrease of viable B 16 cell number. Berberine at concentration $1 \mu \mathrm{g} / \mathrm{ml}$ induced a delayed cytotoxic effect. While after the first $24 \mathrm{~h}$ of influence the increased cell number was monitored, in the next time interval the decrease of cell number was found. The cytotoxic effect of berberine at the next tested concentrations $(0.1,0.01$ and $0.001 \mu \mathrm{g} / \mathrm{ml})$ was directly proportional to the concentration and the time of influence. Similar type of combined cytotoxic effect by monitoring the effects of berberine on proliferation of the HeLa and L1210 cells ${ }^{3}$ was observed. Because of the significant in vitro antiproliferative effects of berberine achieved, the antitumor activity in vivo was investigated. First of all the toxicity of the drug on C57BL/6 mice in the range of concentrations from $10 \mathrm{mg} / \mathrm{kg}$ to $50 \mathrm{mg} / \mathrm{kg}$ was studied and the $\mathrm{LD}_{50}$, less than $50 \mathrm{mg} / \mathrm{kg}$, (for intraperitoneal injection) value was determined. Then the cancerostatic activity in vivo was studied with the transplanted B16 line in the range of doses from $1 \mathrm{mg} / \mathrm{kg}$ to $10 \mathrm{mg} / \mathrm{kg}$. Berberine administered intraperitoneally at doses of 1 and $5 \mathrm{mg} / \mathrm{kg}$ did not affect the weight of the animals. The dose of $10 \mathrm{mg} / \mathrm{kg}$ sligthly reduced the weight of the animals, on day 16 the weight reduction was $6.7 \%$ (Fig. 2). On the other hand, not even tumor volume was affected on day 5, 9 and 12 (Fig. 3). The significant reduction of tumor volume was first observed on day 16 at doses of 5 and $10 \mathrm{mg} / \mathrm{kg}$. The tumor weight on day 16 is shown in Fig. 4. Concentration $1 \mathrm{mg} / \mathrm{kg}$ stimulated the tumor mass, but other tested concentrations, 5 and $10 \mathrm{mg} / \mathrm{kg}$ reduced the tumor weight. We can conclude that after long-term effect berberine has shown anticancer activity on C57BL/6 mice, while the tumor weight and tumor volume reduction are not at the expence of the animal weight.

It is known that the effect of the drug depends on the application dose, way of application and dose interval. The change of application way of berberine and its effect on anticancer activity will be the object of our next studies.

\section{ACKNOWLEDGEMENT}

This study was supported by the Slovak State Committee for Scientific Research VEGA, grant numbers 1/1173/04 and Science and Technology Assistance Agency under the contract No. APVT-20-007304 and APVT-51-019402.

\section{REFERENCES}

1. Shen YJ. Chinese Pharmacology. Shanghai Science and Technology Publishing Company, 1997. p. 50-2.

2. Iizuka N, Miyamoto K, Okita K, Tangoku A, Hayashi H, Yosino S, Abe T, Morioka T, Hazama S, Oka M. (2000) Inhibitory effect of Coptidis Rhizoma and berberine on the proliferation of human esophageal cancer cell lines. Cancer Lett 148, 19-25.

3. Jantová S, Čipák L, Čerňaková M, Koštálová D. (2003) Effect of berberine on proliferation, cell cycle and apoptosis in HeLa and L1210 cells. J Pharm Pharmacol 55, 1143-9. 